\title{
Evaluation of the Comprehensive Ecotourism Suitability and Recognition of Its Key Landscape Pattern Factors (Case Study of Henan Province, China)
}

\author{
Junyuan Zhao', Shengjie Wang'* \\ ${ }^{1}$ School of Business Xinyang College, West section of Xinqi Avenue, Shihe District, Xinyang City, China \\ ${ }^{2}$ College of Geography and Environment Science, Northwest Normal University, \\ No. 967, Anning East Road, Lanzhou 730070, China
}

Received: 29 September 2020

Accepted: 27 November 2020

\begin{abstract}
This paper evaluates the ecotourism suitability of Henan province based on the ecotourism suitability evaluation system. And our research clarifies the spatial distribution of the ecotourism suitability in Henan province, China, explores the internal relations between landscape pattern and ecotourism suitability, and provides a scientific basis for the future sustainable development of ecotourism in Henan from an ecological perspective. The results show the following: 1) the ecotourism suitability is obvious differences between the eastern and western regions in Henan, with the indexes of ecotourism suitability in the western and southern regions being higher than those in other regions. The ecotourism suitability shows a trend of first increasing and then decreasing in Henan, with the highest value in 2007; 2) the Pearson correlation analysis shows that the key landscape pattern factors, including landscape patch area, shape, number, type, and spatial configuration, have an important impact on ecotourism suitability and show significant time differences.
\end{abstract}

Keywords: ecotourism, suitability, landscape pattern index, factor recognition, Henan Province

\section{Introduction}

Tourism has become an important part of people's daily life with the rapid development of China's economy and the improvement of living standards. China's ecological environment has been continuously

*e-mail: wsj_edu@163.com destroyed, which has aroused the government's increasing attention to environmental protection and led to ecotourism gradually becoming an important object of people's focus in recent years [1,2].

As a mode of economic activity to practice the concept of ecological civilization, ecotourism has gradually changed people's understanding of natural ecosystems, providing a new approach for sustainable development of nature conservation. Ecotourism, which emphasizes that we must protect the environment in our activities, is a kind of tourism activity that meets 
tourists' experience needs and develops the economy while protecting the structure and function of natural and social ecosystems [3, 4]. The most commonly used definition is the one established by The International Ecotourism Society (TIES), which states that ecotourism is "Responsible travel to natural areas that conserves the environment and sustains the well-being of local people" [5]. A large number of studies on ecotourism have been conducted on a global scale with the continuous improvement of people's awareness of environmental protection. These studies can be summarized as the assessment of natural scenery, ancient cultural relics (quality, impact, infrastructure, tourists, etc.), carrying capacity and the social and economic value created [6]. Therefore, sustainable development of areas with the contribution of ecotourism is an important issue in the world today [7].

The research on the suitability of ecotourism is currently an important topic to solve the contradiction between human and land, which is related to the harmonious unification of human and nature and the sustainable development of human beings. The evolution of the landscape pattern has caused great changes in the spatial structure of the landscape, and it is intuitively reflected in the structure and composition of the ecosystem, thus affecting the suitability of ecotourism [8-10]. The landscape pattern change is affected by the shape, number, spatial distribution and structure of the ecosystem or the land utilization/cover type [11-13]. It has typical spatial heterogeneity and can effectively reveal the spatial variation characteristics of regional ecological conditions [14, 15]. The impact of human activities on the regional ecological environment can be clarified, and the internal law of landscape pattern evolution can be determined through dynamic analysis of landscape patterns $[16,17]$. This can reveal the internal mechanism of changes in landscape pattern affecting the suitability of ecotourism [18, 19]. Geographic information technology has used different methods in the suitability analysis of ecotourism destinations to identify potential ecotourism development sites in recent years. However, the research on ecotourism suitability assessment is limited to the use of relevant assessment systems to classify the space, and little attention is paid to the internal influencing factors of classification [20-24]. Similar research is not conducive to the future ecotourism planning and development of regions with low ecotourism suitability. For example, the author used the analytic hierarchy process (AHP) to divide the study area into most suitable, suitable, moderately suitable and unsuitable areas for the spatial planning of ecotourism suitability in Baoting County, Hainan Province [25]. The constructed evaluation index system was used to divide the desert tourist destinations into moderate suitability and low suitability to evaluate desert ecotourism suitability [26]. The study only uses the AHP to establish an evaluation index system to qualitatively describe the suitability of carrying out ecotourism activities for the evaluation of the suitability of ecotourism in Snow Mountain [27]. These studies help people to recognize the suitability level of different types of ecotourism, but they do not explore the internal relations from the impact factors and are thus unable to provide a path to promote the future development of regions with poor suitability levels.

Since the introduction of the concept of ecotourism into China in the 1990s, it has grown gradually, due to it's nature correlation with sustainable development and future trends towards it [28]. However, the development of ecotourism is still at a primary phase, with so many natural environments being severely damaged due to overdevelopment, and the contradiction is still very prominent between the specialization of ecotourism and economic benefits [29, 30]. Although the party committee and the provincial government of Henan province also put forward the development strategy of "tourism province" with the overall layout of "two belts (the along the Yellow River ancient tourism belt and the ecological sightseeing belt of the middle route of south-to-north water diversion) and five zones (the Songshan zen culture tourism area, the south Taihang scenic area, the Funiu mountain leisure resorts, the Tongbai-Dabie mountain red and green cultural tourism area and the eastern Henan plain ancient culture ecotourism area)" in 2008 (Fig. 1), there are still many problems. Therefore, it is necessary to ease the tension between ecotourism and tourism-related economic growth by some technical means and methods. The superior geographical conditions and historical and cultural conditions of Henan Province have created abundant natural and human resources, which have the unique advantages of developing ecotourism. However, these superior conditions are accompanied by the relative vulnerability of the ecological environment. For example, the forests in Henan Province have a single structure, low biodiversity and weak forest ecological service functions; serious water ecological environmental problems, serious soil erosion in some areas; unsatisfactory agricultural ecological environment, and ecological damage caused by mining resources development is difficult repair etc [31]. The ecotourism in Henan Province is in a stage of rapid development and immaturity, and it is easy to see the phenomenon of inadequate recognition and improper development. Therefore, the study explores the key landscape pattern factors that affect the suitability of ecotourism and reveals the key points of ecotourism response to landscape pattern through the quantitative representation of the landscape pattern and the suitability of ecotourism by taking the whole province and the city as the unit. The following objectives can be achieved: (1) the existing ecotourism development conditions and future ecotourism development potential can be well understood; (2) it can provide theoretical basis for the government agencies to carry out the macro-control of ecotourism in the province and provide theoretical basis for the tourism developers to carry out the ecotourism site selection; (3) it can provide a theoretical basis for 
the ecotourism scenic spot to carry out the work of ecological system protection and environmental quality restoration with corresponding intensity; (4) it provides the reference advice for the eco-tourists to choose the tourist destination.

\section{Materials and Methods}

\section{Overview of the Study Area}

Henan Province is located in the middle of China and belongs to the middle and lower reaches of the Yellow River. It is adjacent to Shandong, Jiangsu and Anhui in the east, Hebei and Shanxi in the north, Shaanxi in the west, and Hubei in the south. Therefore, has a geographical advantage of extending in all directions (Fig. 1). Its terrain is high in the west and low in the east; Taihang Mountain, Funiu Mountain, Tongbai Mountain, and Dabie Mountain are distributed semi-circularly along the provincial boundaries in the north, west, and south. The central and eastern portions include the Huang-Huai-Hai Alluvial Plain; the southwest area is the Nanyang Basin. Plains and basins, mountains, and hills account for $55.7 \%, 26.6 \%$, and $17.7 \%$ of the total area, respectively. Most regions belong to the warm temperate zone of the climate, and the southern region enters the subtropics, belonging to the continental monsoon climate that transitions from the north subtropics to the warm temperate zone. Meanwhile, it also has the characteristics of transition from the east to the west from the plain to the hilly mountain climate. Therefore, it has the performance of four distinct seasons, the same period of rain and heat, and the complexity and diversity. From the south to the north of the province, the annual average temperature is $10.5-16.7^{\circ} \mathrm{C}$, and the average annual precipitation is $407.7-1295.8 \mathrm{~mm}$, with a peak in June-August. The annual average sunshine is 1285.7-2292.9 hours, and the annual frost-free period is 201-285 days, which is suitable for the growth of various crops. The province is rich in water, animal, plant, forestry and mineral resources in terms of resources. The province has 15 national-level forest parks, 15 provincial-level nature reserves, 2 world cultural heritage sites, 189 nationallevel cultural relic protection units, and 8 nationallevel historical and cultural cities. Therefore, it has a high potential for tourism development. The added value of the tertiary industry accounted for $45.2 \%$ of the province's GDP in 2018, contributing $50.0 \%$ to GDP growth, 4.4 percentage points higher than that of the secondary industry according to the economic growth published on the portal of Henan provincial government. The total tourism revenue of 19 cities in the province was RMB 675.1 billion, showing a rapid growth compared with the previous year. There are 159 scenic spots above Grade 4A, 532 star hotels, and 1199 travel agencies, which received 665.11 million tourists from home and abroad in 2018.

\section{Data Sources}

The data are used for analysis and research from the following five aspects in this paper. 1) Remote sensing

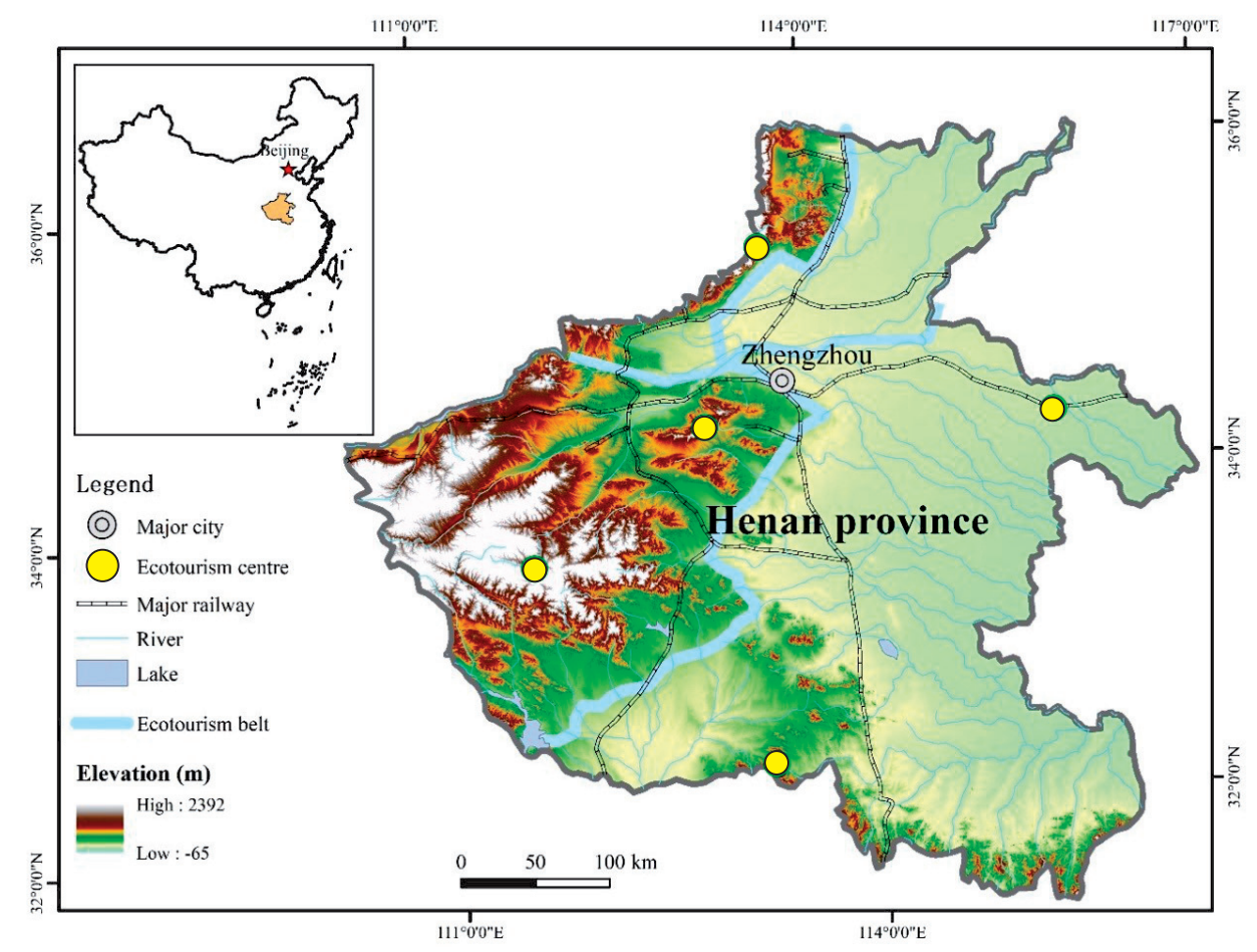

Fig. 1. Overview of the study area (The ecotourism center represents the ecotourism areas). 
data: data of land utilization/cover type derive from MODIS's 4 MCD12Q1 products (2002, 2007, 2012, 2017); the vegetation index data (NDVI data) derive from MODIS's MOD13A1, with the column number of H27v05. The above data derive from the LAADS DAAC data center on the NASA website (https:/ladsweb. modaps.eosdis.nasa.gov/), with a spatial resolution of $500 \mathrm{~m}$. After re-sampling, the resolution is increased to $100 \mathrm{~m}$, and the data quality can meet the research requirements. The digital elevation model (DEM) data are from GS Cloud, with a spatial resolution of $90 \mathrm{~m} * 90 \mathrm{~m}$, and are combined after downloading. 2) The meteorological data are obtained from the "China Meteorological Science Data Sharing Service Network" (http://data.cma.cn). A total of 15 meteorological stations are selected in Henan province and its surrounding areas, including average temperature, precipitation, wind speed, relative humidity and solar radiation. 3) Basic maps: topographic map of Henan (1:250 000), vector administrative boundary (1:250 000), road map (1:250 000), and river and lake map (1:250 000), all of which are from National Geomatic Center of China. 4) Social-economy statistical data: the economy and other statistical data from 1999 to 2017 are obtained from the Henan Provincial Bureau of Statistics. 5) Field research data: first-hand information obtained from two field studies in this province from 2017 to 2018. The perceptual cognition of the local land use situation is through the discussion with business personnel from local relevant departments such as local forestry, water conservancy and nature reserves.

\section{Research Methods}

\section{Ecotourism Evaluation System}

Based on previous studies of ecotourism by experts and scholars, we select 7 spatial indexes as evaluation factors for ecotourism suitability: naturalness (NL) [19], water proximity (WP), traffic proximity (TP), landscape diversity (LD) [32], vegetation coverage (VC), relief suitability (RS) [33] and climate comfort (CC) [34], which are used in the following formula to calculate the composite index of ecotourism suitability [35]:

$$
E_{j}=\sum_{i=1}^{n} \alpha_{i} X_{i j}
$$

...where $E_{\mathrm{j}}$ represents the comprehensive index of ecotourism suitability in the area in year $j ; \alpha_{i}$ represents the weight coefficient of the factor $X_{\mathrm{ij}} ; X_{\mathrm{ij}}$ is the value of factor $X$ in year $j$, and $\mathrm{n}$ is 7. The Jenks Natural Breaks has been used to divide them into five grades when calculating the seven evaluation indexes, so as to highlight their relative importance in space. Meanwhile, the equal weight method is used to enhance the applicability of the results in the research area due to the large research area, namely, $\alpha_{i}=1 / 7$ (Table S1).
The ecotourism evaluation method is used to calculate and evaluate the ecotourism suitability of Henan Province to obtain the comprehensive index of ecotourism suitability in each grid unit. The spatial statistical tool of ArcGIS10.4 is used to calculate the comprehensive index mean of the ecotourism suitability of each city and region, with the mean representing the comprehensive index of ecotourism suitability of each city and use this software to make a spatial distribution map of ecotourism. The equal interval method is used to divide the comprehensive index of ecotourism suitability into 5 levels to compare and analyze the spatial and temporal differences of the comprehensive index of ecotourism suitability.

\section{Selection of Landscape Pattern Indexes}

The land type is divided into six categories: grassland, forestland, urban and rural construction land, waters, wetlands and arable land based on the land utilization status in Henan Province. Because the average land area of the study area is approximately $20 \mathrm{~km}^{2}$, the land-use data space is re-sampled to a $100 \mathrm{~m} * 100 \mathrm{~m}$ grid, and the landscape pattern indexes are calculated separately by province and 19 cities in Fragstats 4.2. Based on the landscape index classification of the international landscape software Fragstats 4.2, 14 landscape pattern indexes are selected to quantitatively characterize the spatial and temporal characteristics of landscape patterns in Henan Province (Table S2). It involves six aspects of the landscape area, landscape density, landscape shape, landscape proximity, landscape vergence, and landscape diversity.

\section{Pearson Correlation Analysis Measure Method}

In SPSS22.0 software, Pearson correlation coefficient method was used for analysis of correlation between landscape pattern factors and ecotourism suitability of the study region. Two significance levels $(0.05$ and 0.01$)$ were set and two-tailed test was performed. On this basis, the key landscape pattern indexes that can influence the ecotourism suitability of the study region in different periods can be identified.

$$
C\left(Y, X_{i}\right)= \pm \max \left\{\left|C_{1}\left(Y, X_{i}\right)\right|,\left|C_{2}\left(Y, X_{i}\right)\right|\right\}
$$

$C_{2}\left(Y, X_{i}\right)= \pm \max \left\{\left|C_{1}\left(\ln Y, X_{i}\right)\right|,\left|C_{1}\left(Y, \ln X_{i}\right)\right|,\left|C_{1}\left(\ln Y, \ln X_{i}\right)\right|\right\}$

...where $Y$ is ecological security index, $X i$ is the $i$ landscape pattern index, $C 1(Y, X i)$ is the Pearson correlation coefficient between $Y$ and $X i, C 2(Y, X i)$ is the Pearson correlation coefficient between $Y$ and $\ln X i, C(Y, X i)$ is the Pearson correlation coefficient between $\mathrm{Y}$ and $\mathrm{Xi}$. The sign (positive or negative) of coefficient is consistent with that of the original value. 


\section{Results}

\section{Spatial and Temporal Changes of Ecological \\ Tourism Suitability in Henan Province} from 2002 to 2017

\section{Time Variation of Ecotourism Suitability in Henan Province}

The comprehensive index of ecotourism suitability of each city in Henan Province was obtained according to the evaluation method of ecotourism suitability (Fig. 2). The results show that the time difference of the eco-tourism suitability comprehensive index of each city in Henan Province from 2002 to 2017 is relatively significant. Among them, 7 cities including Luoyang City and Jiyuan City showed an inverted U-shaped change trend. The highest value appeared in 2007, and these cities accounted for $38.89 \%$ of the total number of cities. This shows that the ecological environmental protection measures implemented by these cities before 2007 have achieved good results, but after 2007, they have returned to the previous level, and the ecological environmental protection measures have not been well continued. Anyang city and other four cities also showed an inverted U-shaped change trend, accounting for $22.22 \%$ of the total number of cities, with the highest value in 2012. This shows that the ecological environmental protection measures of these cities lasted longer than those of Luoyang and other cities, but did not continue after 2012. The four cities, including Jiaozuo City, exhibited an $\mathrm{N}$-shaped change trend in which the ecotourism suitability index increased first, then decreased, and then increased, accounting for $22.22 \%$ of the total number of cities. This shows that the implementation and effect of ecological environmental protection and governance measures in these cities are changing in stages. The comprehensive index of ecotourism suitability of Xinyang City and Zhumadian City showed a U-shaped change trend, the lowest value appeared in 2007, accounting for $11.11 \%$ of the total number of cities. This shows that the implementation and effects of ecological environmental protection measures in Xinyang City and Zhumadian City are slower than those in other cities. The comprehensive index of ecotourism suitability in Zhoukou City showed an upward trend, accounting for $5.56 \%$ of the total number of cities. This shows that the ecological environment protection measures of Zhoukou City have been effectively extended.

Through the above analysis, we can get that Henan Province generally adopted the ecological environmental protection measures vigorously promoted by the state before the 2008 Beijing Olympic Games, so that the ecological environment of the province has been well improved and the suitability of ecological tourism has been enhanced. However, after the Olympic Games, ecological environmental protection measures have not been further extended, which has caused damage to the ecological environment and reduced the suitability of ecotourism. In addition to the important influencing factor of the implementation intensity of environmental protection, topographical factors, changes in people's environmental awareness and the intensity of local tourism will all have an important impact on the suitability of ecotourism in this area.

\section{Spatial Variation of Ecotourism Suitability in Henan Province}

The ecotourism suitability was evaluated to clearly identify the spatial difference by taking cities as the

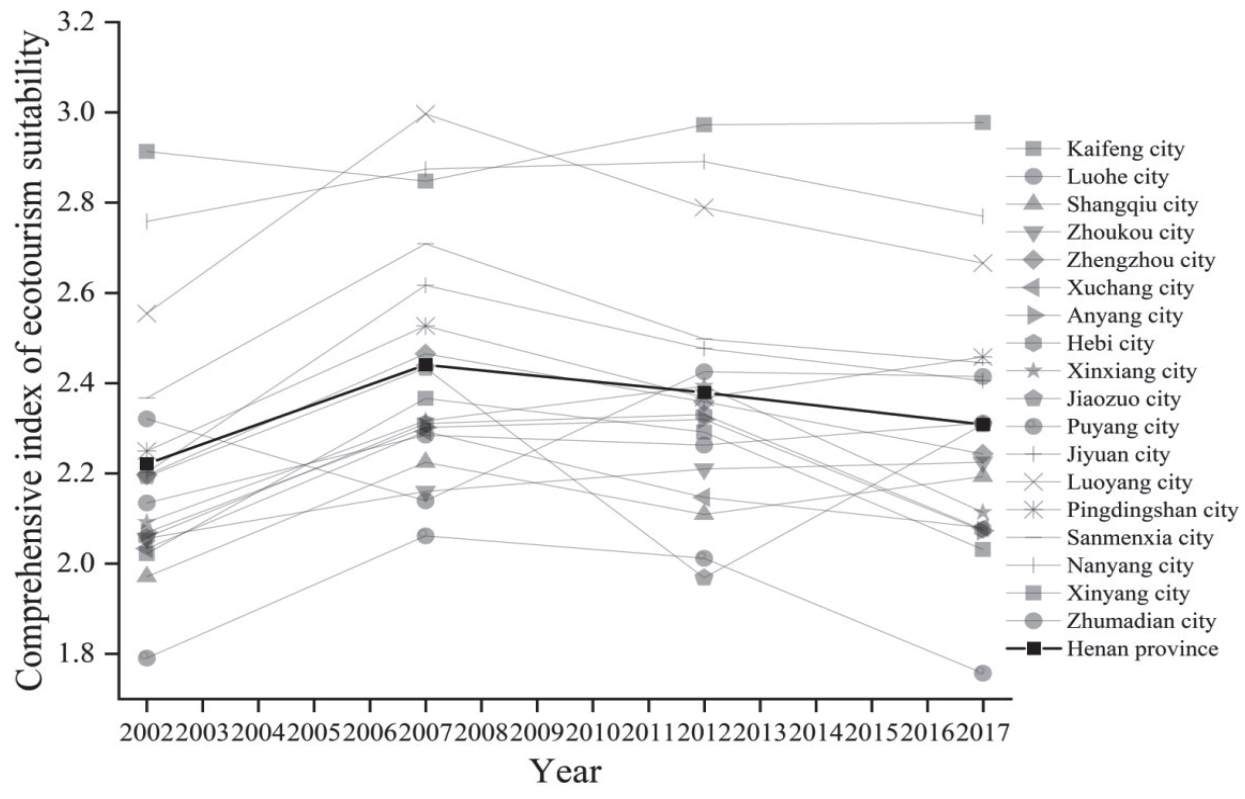

Fig. 2. Dynamic changes of the comprehensive index of ecotourism suitability in Henan Province from 2002 to2017. 
unit in 2002, 2007, 2012 and 2017 (Fig. 3). In addition, the areas occupied by ecotourism suitability by city were counted in 2017 (Table 1).

The results showed that there were significant spatial differences in the comprehensive index of ecotourism suitability among different cities in Henan province (Fig. 3). The spatial pattern of the comprehensive index of ecotourism suitability is basically the same in 2002, 2007, 2012 and 2017, showing a spatial pattern of hierarchical distribution from northeast to southwest and gradually increasing from northeast to southwest. Among them, compared with other years in 2007, the comprehensive index of ecotourism suitability increased from Lowest and Lower grades to Higher and Highest grades in Zhengzhou and Kaifeng city, Jiaozuo city and Xinxiang city in south, Pingdingshan city in Luoyang city and northern part of Xuchang city, and the number of Higher and Highest grades in the whole region increased significantly. This shows that the ecological environment management and protection measures carried out before 2007 have achieved good results, the ecological environment has been significantly improved and the ecotourism suitability of the whole province has increased.
In order to clarify the suitability level of ecotourism in various cities of Henan province, we made statistics on the percentage of each grade in the area (Table 1, Fig. 3). The results show that the area proportion of Xinyang city reaches $32.08 \%$ in the Highest ecotourism suitability region, and the area proportion of Higher reaches $51.60 \%$. This shows that Xinyang City is the most suitable for ecotourism development. Secondly, there are Luoyang City and Nanyang City. The area proportion of Highest is more than $20 \%$, and the area proportion of Higher is also high. It is also possible to develop ecotourism. The cities that can be considered for proper ecotourism development are Jiyuan City and Sanmenxia City, and their Highest and Higher areas account for more than the remaining cities. The ecotourism suitability of the remaining cities is mainly less suitable and generally suitable. It is more difficult to develop ecotourism before the current situation is changed. It is appropriate to carry out small-area and small-scale ecotourism development or not to carry out ecotourism development.
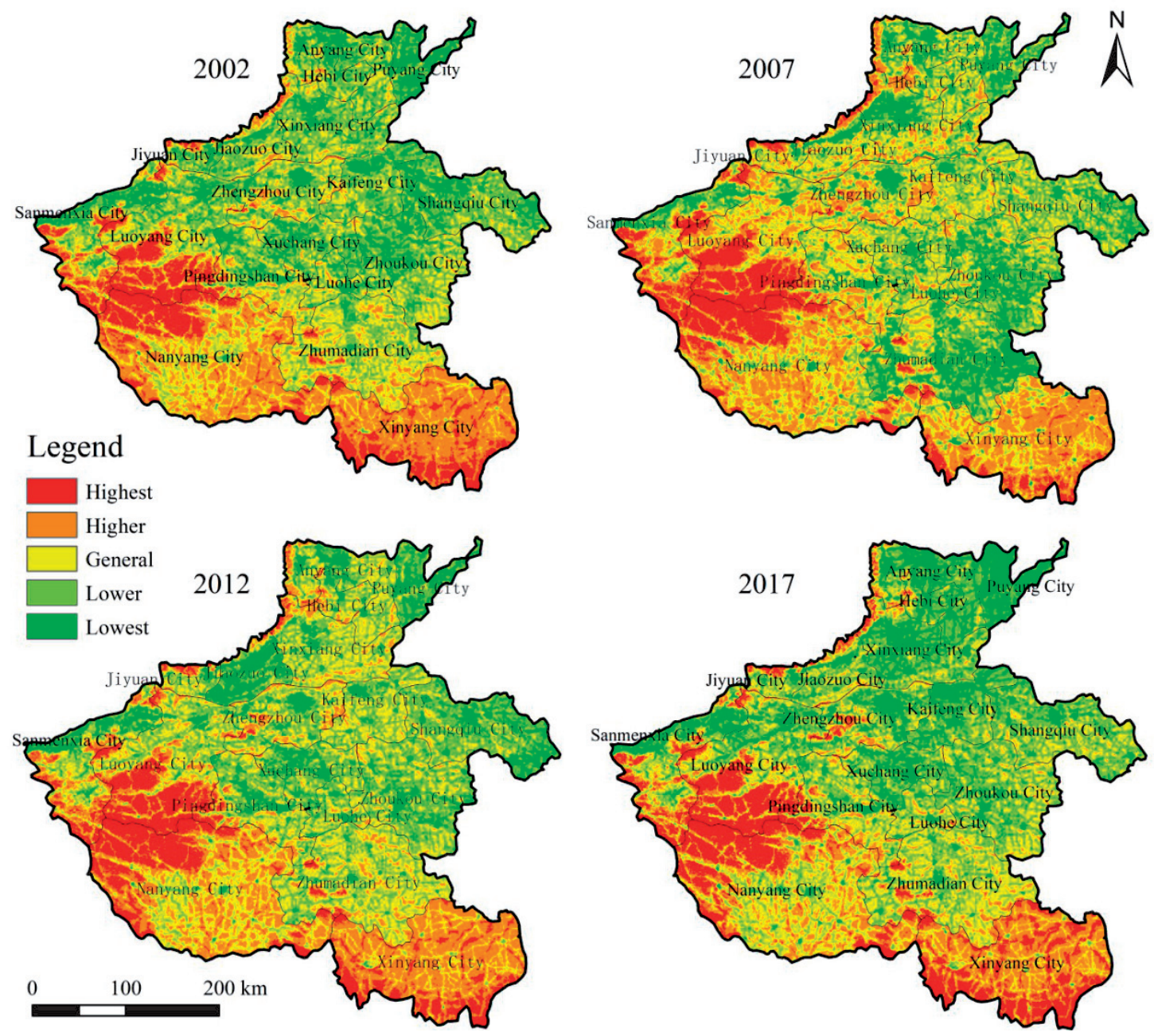

Fig. 3. Spatial pattern of ecotourism suitability in Henan Province in 2002, 2007, 2012 and 2017. 
Table 1. Proportion of eco-tourism suitability grade area of each city in Henan Province in 2017.

\begin{tabular}{|c|c|c|c|c|c|}
\hline Name & Lowest & Lower & General & Higher & Highest \\
\hline Xinyang City & 0.06 & 1.21 & 15.05 & 51.60 & 32.08 \\
\hline Luoyang City & 8.06 & 24.70 & 23.88 & 13.78 & 29.58 \\
\hline Nanyang City & 1.05 & 10.23 & 37.35 & 28.66 & 22.71 \\
\hline Sanmenxia City & 19.01 & 23.62 & 24.09 & 17.85 & 15.42 \\
\hline Jiyuan City & 10.58 & 35.26 & 33.01 & 10.79 & 10.36 \\
\hline Pingdingshan City & 6.71 & 30.95 & 39.95 & 14.56 & 7.82 \\
\hline Jiaozuo City & 12.60 & 42.36 & 33.37 & 8.37 & 3.30 \\
\hline Zhenzhou City & 20.96 & 39.05 & 27.28 & 9.55 & 3.16 \\
\hline Zhumadian City & 2.84 & 32.22 & 52.31 & 10.15 & 2.49 \\
\hline Xinxiang City & 29.82 & 46.96 & 17.58 & 3.80 & 1.84 \\
\hline Anyang City & 34.28 & 47.75 & 12.16 & 4.60 & 1.21 \\
\hline Hebi City & 33.35 & 46.98 & 15.29 & 3.64 & 0.74 \\
\hline Luohe City & 9.43 & 37.95 & 45.89 & 6.46 & 0.28 \\
\hline Xuchang City & 26.97 & 56.07 & 15.53 & 1.27 & 0.16 \\
\hline Zhoukou City & 9.51 & 54.66 & 33.39 & 2.45 & 0.00 \\
\hline Shangqiu City & 11.04 & 58.43 & 29.25 & 1.28 & 0.00 \\
\hline Kaifeng City & 33.11 & 53.09 & 13.39 & 0.40 & 0.00 \\
\hline Puyang City & 77.22 & 22.10 & 0.67 & 0.00 & 0.00 \\
\hline
\end{tabular}

Analysis of Impact Factors on the Ecotourism Suitability in Henan Province from 2002 to 2017

\section{Spatial and Temporal Changes of Landscape Pattern Indexes}

The landscape pattern index of each city in 2002 , 2007, 2012 and 2017 is calculated with the city as the unit, and the spatial distribution map is generated in Arcgis10.2 (Table 2) to analyze the spatial characteristics of landscape pattern change in Henan Province and to study the response of urban ecotourism suitability to landscape patterns.

In terms of the area density index, the spatial variation of provincial landscape fragmentation degree is obvious in the four periods, and the landscape fragmentation degree in central and eastern regions is lower than that in western and southern regions. The results show that the MPS high-value areas were mainly concentrated in the eastern and western regions from 2002 to 2017. It presents the spatial pattern of "West East High, Central Low", and shows a trend of increasing first and then decreasing. The spatial distribution of PD and ED has a strong consistency in the four periods, and it shows the opposite spatial distribution pattern with LPI. The high-value areas of LPI are mainly distributed in Pingdingshan City and Puyang City, and the low-value areas are mainly distributed in Jiaozuo
City and Nanyang City and Xinyang City in the south. PD and ED are mainly dominated by low-value areas, and high-value areas appear in Jiaozuo City, presenting a spatial pattern of "high in the middle and low in the surroundings" and showing an increasing trend.

In terms of the shape index, the spatial distributions of the AWMSI indexes were more complicated at the four time points, showing that the complexity of the landscape patch shape in the southwest was higher than that in the northeast. The high-value areas of AWMSI were mainly distributed in Nanyang City and Xinyang City in 2002. The spatial distribution of AWMSI has an upward trend with the evolution of time. The AWMSI extended from the southwest through the middle to the northeast after 2012, showing a spatial pattern of "high in the south and central area, and low in the east and west". The LSI distributions were relatively regular from 2002 to 2017, showing a spatial pattern of "high in the south and west, and low in the north and east". Both AWMSI and LSI indexes showed a trend of decreasing first and then increasing of time variation, indicating that the complexity of landscape shape first decreased and then increased.

In terms of the vergence index, the fragmentation and dispersion in the west at the four time points were more significant than in the east. The MPI showed a spatial pattern of "high in the west and low in the east" from 2002 to 2017, and MNN showed a spatial pattern of "high in the south and west, and low in the north and 
Table 2. The changes of the landscape pattern index in 2002-2017.

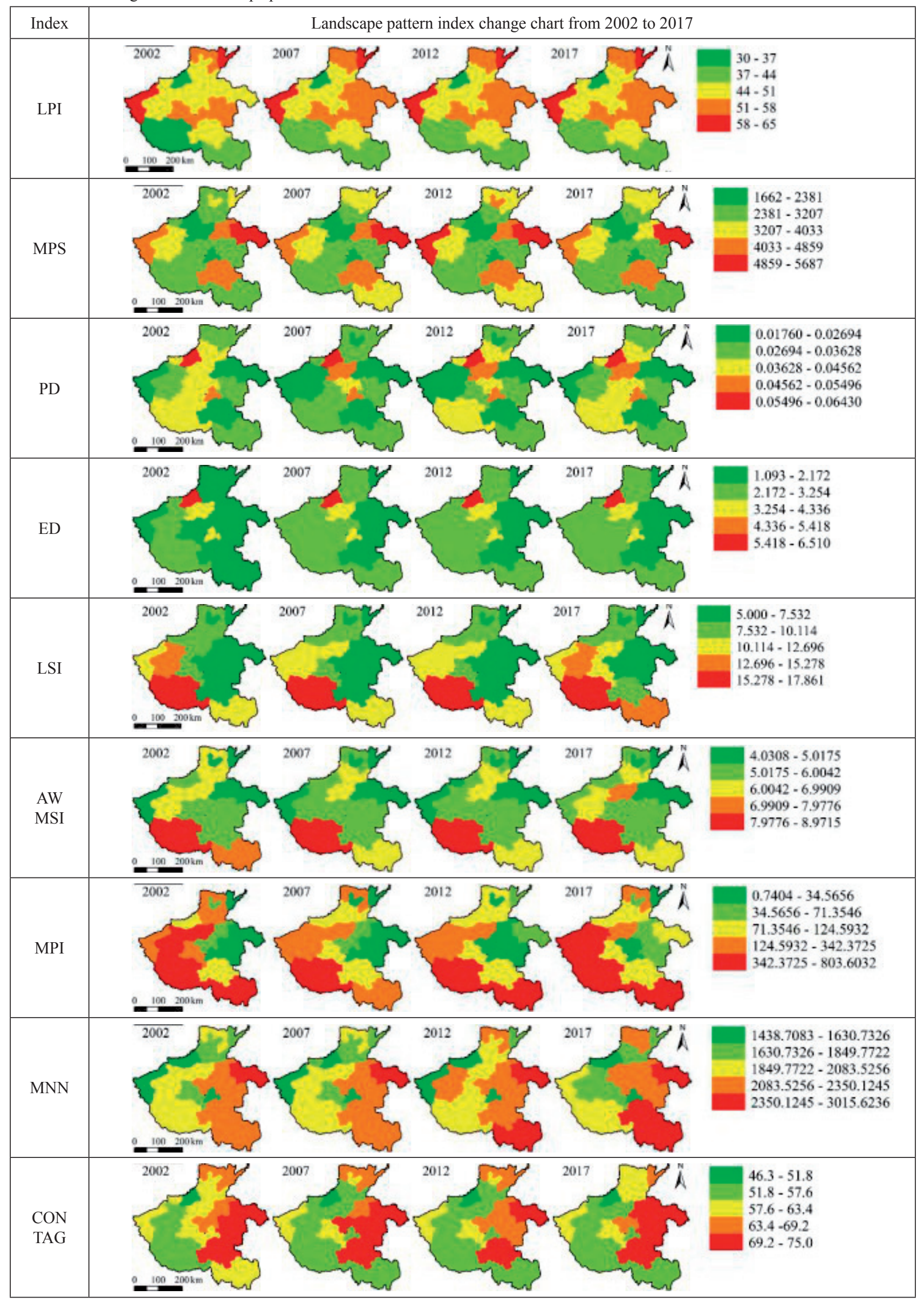


Table 2. Continued.

SHDI

east". The spatial distribution patterns of CONTAG and AI were consistent, showing a pattern of "high in the east and low in the west" and good connectivity in the landscape patches in the east. While the spatial pattern of SPLIT was just the opposite, showing a pattern of "high in the west and low in the east".

In terms of the diversity index, the distributions of landscape diversity were not obvious at the four time points. The spatial distributions of SHDI and SHEI were consistent, showing a spatial pattern of "high in the west and low in the east" and tending to gradually decrease. This result indicates that the balance of landscape types is decreasing and homogeneity is increasing.

\section{Recognition of Key Landscape Factors Affecting Ecotourism Suitability}

The Pearson correlation coefficient method is used to analyze the comprehensive indexes of ecotourism suitability and 14 landscape indexes representing landscape characteristics in 2002, 2007, 2012 and 2017. A two-tailed test is performed at significance levels of 0.05 and 0.01 to analyze the correlation, thus determining the key landscape pattern factors that affect ecotourism (Table 3 ).

The correlation analysis results show that there is a significant correlation between ecotourism and multiple landscape pattern indexes (Table 3). Although this correlation fluctuates in time, it does not change the level of correlation between them as a whole. The following is a specific correlation analysis of ecotourism suitability and landscape pattern index.

In 2002, TA, LSI, AWMSI, MPI, and SHDI were closely related to the comprehensive index of ecotourism suitability at a significance level of 0.01 , with correlation coefficients of $0.741,0.854,0.742$, 0.814, and 0.659, respectively. LPI, CONTAG, SPLIT, and SHEI were closely related to the comprehensive index of ecotourism suitability at a significance level of 0.05 , with correlation coefficients of $-0.501,-0.473$, 0.558 , and 0.587 , respectively. These results show that the single landscape patch and continuity have an important impact on ecotourism during these periods. The main reason is that the higher the degree of fragmentation of the landscape patches, the higher the balance of the distribution of landscape patches, which helps to improve ecotourism.

In 2007, LSI, AWMSI, MPI, SHDI and SHEI were closely related to the comprehensive index of ecotourism suitability at a significance level of 0.01 , with correlation coefficients of $0.831,0.816,0.694$ and 0.709, respectively. TA, AWMSI, CONTAG and SPLIT were closely related to the comprehensive index of ecotourism suitability at a significance level of 0.05 , with correlation coefficients of $0.555,0.504,-0.584$ and 0.534 , respectively. It can be seen that the size and connectivity of the dominant landscape have a great negative impact on ecotourism. Meanwhile, the connectivity between similar landscapes has a positive impact on ecotourism. The better the connectivity 
Table 3. The correlation between the comprehensive indexes of ecotourism suitability and landscape pattern index from 2002 to 2017.

\begin{tabular}{|c|c|c|c|c|}
\hline \multirow{2}{*}{$\begin{array}{c}\text { Landscape Pat- } \\
\text { tern Index }\end{array}$} & \multicolumn{4}{|c|}{ Ecotourism Suitability } \\
\cline { 2 - 5 } & 2002 & 2007 & 2012 & 2017 \\
\hline TA & $0.741^{* *}$ & $0.555^{*}$ & $0.756^{* *}$ & $0.693^{* *}$ \\
\hline LPI & $-0.501^{*}$ & -0.348 & -0.246 & -0.437 \\
\hline MPS & -0.147 & -0.085 & 0.150 & -0.097 \\
\hline PD & 0.064 & 0.028 & -0.266 & 0.072 \\
\hline ED & 0.221 & 0.291 & -0.107 & 0.219 \\
\hline LSI & $0.854^{* *}$ & $0.831^{* *}$ & $0.747 * *$ & $0.779 * *$ \\
\hline AWMSI & $0.742^{* *}$ & $0.504 *$ & $0.571^{*}$ & $0.596^{* *}$ \\
\hline MPI & $0.814^{* *}$ & $0.816^{* *}$ & $0.853 * *$ & $0.791^{* *}$ \\
\hline MNN & -0.054 & -0.142 & 0.253 & 0.062 \\
\hline CONTAG & $-0.473^{*}$ & $-0.584 *$ & -0.201 & -0.438 \\
\hline SPLIT & $0.558^{*}$ & $0.534^{*}$ & 0.104 & 0.404 \\
\hline AI & -0.237 & -0.302 & 0.093 & -0.233 \\
\hline SIDI & $0.659^{* *}$ & $0.694^{* *}$ & 0.440 & $0.598^{* *}$ \\
\hline SHEI & $0.587^{*}$ & $0.709^{* *}$ & 0.369 & $0.546^{*}$ \\
\hline
\end{tabular}

${ }^{*} \mathrm{p}<0.05,{ }^{* *} \mathrm{p}<0.01$

of the similar landscape patches and the richer the landscape types in the region will make the higher the comprehensive index of ecotourism suitability.

In 2012, TA, LSI and MPI were closely related to the comprehensive index of ecotourism suitability at a significance level of 0.01 , with correlation coefficients of $0.756,0.747$, and 0.853 , respectively. AWMS was closely related to the comprehensive index of ecotourism suitability at a significance level of 0.05 , with a correlation coefficient of 0.571 . These results show that the landscape shapes have become more and more complex and irregular with the increase of the intensity of land development and utilization by human activities. The more abundant the landscape types, the more conducive to the improvement of ecotourism level.

In 2017, TA, LSI, AWMSI, MPI and SHDI were closely related to the comprehensive index of ecotourism suitability at a significance level of 0.01 , with correlation coefficients of $0.693,0.779,0.596,0.791$ and 0.598 , respectively. SHEI was closely related to the comprehensive index of ecotourism suitability at a significance level of 0.05 , with a coefficient of 0.546 . These results show that the enhancement of human activities causes significant changes in the landscape shape, fragmentation and connectivity. The higher the degree of landscape fragmentation, the more abundant the types, and the more complex the shapes, the more beneficial it is to improve the level of ecotourism.
To sum up, the landscape pattern factors that are closely related to the suitability of ecotourism have many factors and have a high correlation, indicating that changes in landscape patterns have a strong comprehensive influence on the suitability of ecotourism.

\section{Discussion}

\section{Evaluation Method}

Ecotourism is a new approach to tourism resource development and the tourist experience [36]. The ecotourism suitability is an important internal driving factor for the change of tourism intensity, and the evaluation of its spatial and temporal patterns is helpful to explain the spatial and temporal changes of tourism intensity [37]. Ecotourism suitability evaluation is the evaluation of ecotourism suitability in the strict sense of regional development, which can provide a scientific basis for the development of ecotourism in various regions according to local conditions and is a powerful tool for implementing the concept of ecotourism in ecotourism destinations [38]. The differences between the landscape suitability can be used to guide a region to adopt different spatial control intensities from "hard" to "soft" to develop ecotourism and meet the tourism needs of different types of tourists in "hard-soft" [39]. At present, scholars are paying more and more attention to the research on ecotourism suitability and focusing on the evaluation criterion of ecotourism suitability [40-42]. Although the differences of the conditions of various study areas and the difficulties in obtaining spatial data make the evaluation criterion selected in previous studies different, it is not difficult to show that naturalness is the most important criterion, whether it is represented directly by naturalness or indirectly by the distribution of wildlife, the original ecology and vegetation cover [43]. Multi-objective decision making is the main method for suitability evaluation, assigning values to the development suitability of various regions according to the evaluation criteria and weighting each criterion by AHP [26], Delphi [44] and other methods to calculate the final suitability results of these regions. With the development of geographic information system (GIS) technology, the multi-objective decision method and GIS technology are combined to make the analysis and evaluation of ecotourism suitability more accurate and reliable, which has been effectively explored by many scholars at home and abroad [45]. The seven evaluation indexes selected for the evaluation of ecotourism suitability in this paper are all characterizations of landscape naturalness and have clear goals, which avoid the subjective selection of evaluation criterion to a certain extent. The spatial and temporal pattern changes of the landscape pattern and ecotourism suitability in Henan Province are analyzed by constructing a landscape pattern index and an 
ecotourism suitability evaluation model. The purpose is to analyze the relationship between landscape pattern and ecotourism suitability development, and to contribute to the development of ecotourism. Landscape pattern and ecotourism suitability analysis is a very complex process, which involves a variety of factors and is difficult. More scientific evaluation indexes should be selected for evaluation. The regional ecotourism suitability grade standard should be classified according to the existing studies, which still needs further discussion. In addition, the selection of landscape index is mainly made through reading literature and understanding of landscape index, which is too subjective. The selected landscape index may not all well reflect the relationship with the suitability change of ecotourism. Therefore, it is necessary to better construct a new evaluation index system for ecotourism suitability, and use more scientific research methods to study ecotourism suitability and its landscape impact factors.

\section{Relationship between Ecotourism Suitability and Landscape Pattern and Actual Development}

The regional ecological environment is deeply affected by landscape pattern changes and the evolution of landscape patterns can cause great changes in the spatial structure of a landscape [16]. A series of ecological problems caused by unreasonable land use will cause changes in landscape pattern to varying degrees [46-48]. The results show that the level of ecotourism suitability is significantly influenced by the key landscape pattern index in this study (Table 3). In order to further understand the relationship between landscape pattern index and ecotourism suitability, the key landscape pattern index which has reached a significant level of ecotourism suitability was comprehensively analyzed. The results showed that LSI, AWMSI, MPI, CONTAG and SPLIT all affect the level of ecotourism suitability mainly by affecting the "agglomeration effect" of landscape. The higher agglomeration of landscape patches may affect the suitability of ecotourism by mainly affecting the NL, TP, LD and RS in the evaluation system of ecotourism. There is a significant positive correlation between ecotourism suitability and SHDI and SHEI representing diversity, which can also prove this argument to some extent. In addition, TA may also influence the suitability level of ecotourism by expanding the scope of landscape to increase the NL, LD, CC, etc. It can be concluded that the changes of key landscape patterns will affect the suitability level of ecotourism by influencing various elements in the evaluation system of ecotourism through the above comprehensive analysis. Such influences are not single, but mutual.

Since the "two belts and five zones" ecotourism development strategy was put forward by Henan province in 2008 , the suitability of ecotourism in Henan province has also shown a significant change in space over time. By comparing our research results with "two belts and five zones", we can find that, except for the poor consistency between the eastern Henan plain ancient culture ecotourism area and our research results, other "two belts and four zones" have different degrees of consistency with our research results on the whole (Fig. 1). This is because the factors selected for the suitability of ecotourism are mainly from the natural aspects and lack of factors in the aspect of human landscape in this paper. Eastern Henan plain ancient culture ecotourism area is mainly composed of human landscape, so it showed poor ecotourism suitability, and the natural landscape is the main part of the along the Yellow River ancient tourism belt, ecological sightseeing belt of the middle route of southto-north water diversion, Songshan zen culture tourism area, south Taihang scenic area, Funiu mountain leisure resorts and Tongbai-Dabie mountain red and green cultural tourism area has a higher consistency with our research results. The suitability of ecotourism in other ecotourism areas has shown a decreasing trend, except for the Tongbai-Dabie mountain red and green cultural tourism area after more than 10 years of development. Therefore, these areas should pay more attention to the protection of the ecological environment and develop on the basis of protection.

Landscape change is the most visualized sign of land utilization/land cover change and the interaction mechanism between the changes of land utilization and landscape patterns is the focus of studies of global environmental changes [11]. Landscape pattern changes are a comprehensive reflection of a variety of natural and man-made factors or ecological processes on a certain scale of the ecological environment system [49]. The natural attributes and complexity of landscape types are visually reflected in the structure and composition of the ecosystem, thus affecting the changes of ecotourism suitability [50-52]. The tourism industry in Henan has experienced explosive growth since the beginning of the 21 st century. The number of tourists reached 750 million in 2017, an increase of 14.6 times compared with 2002, and the tourism revenue reached RMB 77 billion, an increase of 2.5 times compared with 2002 . The tourism intensity reached a historical level and the tourism carrying capacity continued to increase and was severely tested [53]. The increase of the number of tourists in the region and the continuous construction of infrastructure continuously impact the natural attributes of the ecosystem, thus affecting the fragmentation, shape, connectivity, and diversity of the regional landscape, directly affecting the regional ecological environment, and changing the ecosystem [54]. The continuous development of ecotourism resources has led to the rapid increase in the human demand for ecological carrying capacity (ecological footprint), resulting in a scissors difference in which the ecological carrying capacity demand is greater than the supply and forming an ecotourism suitability small regionalization 
mode [55]. This situation not only endangers the living environment and ecological needs of the local people but also exacerbates the difficulty of ecological governance and poses hidden dangers for regional sustainable development [56-58]. This paper finds that there is a close relationship between the landscape pattern indexes and the ecotourism suitability in the spatial pattern, and changes in the landscape pattern indexes can affect changes in the ecotourism suitability through the evaluation of the landscape pattern indexes and the correlation analysis of the ecotourism suitability indexes. Therefore, future ecotourism planning and management in Henan Province should start from the key landscape pattern factors (area, shape, proximity, and diversity) that significantly affect the development of ecotourism to change the land-use types reflected by the key landscape pattern factors. It can provide a guarantee for the sustainable development of ecological tourism in Henan Province. However, the study does not provide an effective and reasonable explanation for the change process of the landscape pattern indexes and the change mechanism of ecotourism suitability. Thus, the issue of how landscape patterns affect the change of ecotourism suitability is still an important part of future research

\section{Conclusions}

The comprehensive ecotourism suitability evaluation model and the landscape index model are used to evaluate the spatial and temporal changes of the ecotourism suitability and landscape patterns in Henan Province from 2002 to 2017 in this paper. The quantitative method is used to explore the key landscape pattern factors that affect the ecotourism suitability. The following conclusions can be drawn from the analysis: 1) The spatial-temporal difference in the suitability of ecotourism in Henan Province is significant by evaluating the suitability of ecotourism from two scales of time and space. The temporal changes in ecotourism suitability are mainly inverted U-shaped changes, accounting for $61.12 \%$, and the other three types of changes accounting for $38.88 \%$. The ecotourism suitability of Henan province shows an increasing trend from the northeast to the southwest, and the spatial pattern changes little. Among them, Xinyang city, Luoyang city and Nanyang city have a large area with high level of ecotourism suitability, which is most suitable for the development of ecotourism. 2) This paper makes an in-depth analysis of the key ecological processes that play an important role in the suitability of ecotourism from the perspective of landscape pattern, and identifies the key landscape pattern factors. The area, shape, number, type and spatial configuration of landscape patches have an important impact on ecotourism suitability and show a significant time difference. The ecotourism suitability is significantly related to TA, LSI, AWMSI, MPI, and
SHDI in 2002, significantly related to LSI, AWMSI, MPI, SHDI, and SHEI in 2007, significantly related to TA, LSI and MPI in 2012, and significantly related to TA, LSI, AWMSI, MPI, and SHD in 2017. There are multiple landscape pattern indexes and ecotourism suitability indexes showing a significant correlation from 2002 to 2017. The results indicated that the shape, fragmentation and connectivity of the landscape have changed significantly with the enhancement of human activities. The higher the degree of landscape fragmentation, the richer the landscape, and the more complex, the more beneficial it is to improve the level of ecotourism. The higher the degree of fragmentation, the richer and more complex the landscape is, the more conducive to the improvement of the ecotourism level. Therefore, the change of landscape pattern affects the suitability level of ecotourism.

\section{Acknowledgements}

We gratefully acknowledge the support for this research by Henan Soft Science Research Project (No. 192400410292); Henan Higher Education Key Research Project of the Education Department of Henan Province (No. 20A630031); Xinyang Soft Science Research Project (No. 20190039). We thank the anonymous reviewers for their useful suggestions and comments.

\section{Conflict of Interest}

The authors declare no conflict of interest.

\section{References}

1. STEPHEN W., JOHN N. Ecotourism (Second Edition). J. VASC. SURG. 42 (4), 241, 2005.

2. NAVEH Z. From biodiversity to ecodiversity: a landscapeecology approach to con-servation and restoration. Restor. Ecol. 2, 180, 1994.

3. LINDBERG K., MCKERCHER B. Ecotourism: a critical overview, Pac. Tour. Rev. 1997.

4. BEN M., YIN R.S., ZHENG J., WEN Y.L., HOU Y.L. Estimating the social and ecological impact of communitybased ecotourism in giant panda habitats. J. Environ. Manage. 250, 1, 2019.

5. Ecotourism explorer, 2002. http://www.ecotourism.org. The International Ecotourism Society (TIES).

6. HALL C.M., PAGE S.J. Geography of Tourism and Recreation: environment, place and space. Taylor \& Francis e-Library. 2006

7. KIPER T. Role of ecotourism in sustainable development. Adv. Landscape. Architect. 31, 773, 2013.

8. XIAO S.C., XIAO H.L.,, PENG X.M., SONG X. Hydroclimate-driven changes in the landscape structure of the terminal lakes and wetlands of the China's Heihe River Basin. Environ. Monit. Assess. 187 (1), 4091, 2015. 
9. LIU J.Y., KUANG W.H., ZHANG Z.X., XU X.L., QIN Y.W., NING J., ZHOU W.C. Basic Characteristics and Spatial Patterns of Land Use Change in China since the 1980s (English). J. Geogr. Sci. 24 (02), 195, 2014.

10. WANG Y.H., DAI E.F., YIN L., MA L. Land use/land cover change and the effects on ecosystem services in the Hengduan Mountain region, China. Ecosyst. Serv. 34, 55, 2018.

11. QUIGLEY T.M., HAYNES R.W., HANN W.J. Estimating ecological integrity in the inte-rior Columbia River basin. Forest. Ecol. Manag. 153, 161, 2001.

12. FU B.J., CHEN L.D., MA K.M. Principle and Application of Landscape Ecology. Science Press, Beijing, 188, 2002.

13. SU S.L., XIAO R., JIANG Z.J., ZHANG Y. Characterizing landscape pattern and ecosystem service value changes for urbanization impacts at an eco-regional scale. Appl. Geogr. 34, 295, 2012.

14. MOTTET A., LADET S., NATHALIE C., GIBON A. Agricultural land-use change and its drivers in mountain landscapes: A case study in the Pyrenees. Agr. Ecosyst. Environ. 114 (2-4), 296, 2006.

15. MA L.B., BO J., LI X.Y., FANG F., CHENG W.J. Identifying key landscape pattern indices influencing the ecological security of inland river basin: The middle and lower reaches of Shule River Basin as an example. Sci. Total. Environ. 674, 424, 2019.

16. DAILY G.C. Natures services: societal dependence on natural ecosystems. Washington D C: Island Press, 1997.

17. ZHAO Q.J., WEN Z.M., CHEN S.L, DING S., ZHANG M.X. Quantifying Land Use/Land Cover and Landscape Pattern Changes and Impacts on Ecosystem Services. Int. J. Environ. Res. Public Health. 17 (1), 126, 2019. doi:10.3390/ijerph17010126

18. ZHANG L.Q., PENG J., LIU Y.X., WU J.S. Coupling ecosystem services supply and human ecological demand to identify landscape ecological security pattern: A case study in Beijing-Tianjin-Hebei region, China. Urban. Ecosyst. 20, 701, 2017.

19. HOU L., WU F.Q., XIE X.L. The spatial characteristics and relationships between landscape pattern and ecosystem service value along an urban-rural gradient in Xi'an city, China. Ecol. Indic. 108, 105720, 2020.

20. COSTANZA R., NORTON B.G., HASKELL B.D. Ecosystem health: new goals for environmental management. Ecosyst. Heal. N. Goals. Environ. Manage. 234, 1992.

21. LEE J.T., ELTON M.J., THOMPSON S. The role of GIS in landscape assessment: using land-use-based criteria for an area of the Chiltern Hills Area of Outstanding Natural Beauty. Land. Use. Pol. 16, 23, 1999.

22. HEGGEM D.T., EDMONGS C.M., NEALE A.C., BICE L., JONES K.B. A landscape ecology assessment of the Tensas Rivier Basin. Environ. Monit. Assess. 64, 41, 2000.

23. SERVEISS V.B. Applying ecological risk principles to watershed assessment and management. Environ. Manag. 29, 145, 2002.

24. GIGOVIC L.J., PAMUCAR D., LUKIC D., MARKOVIC S. GIS-Fuzzy DEMATEL MCDA model for the evaluation of the sites for ecotourism development: A case study of "Dunavski ključ" region, Serbia. Land. Use. Pol. 58, 348, 2016.

25. YAN F.Y., HE Z.N., FAN S.C. Research on Spatial Planning Strategies Based on the Evaluation of Ecotourism Suitability: A Case Study of Baoting County, Hainan Province. Arch. Culture. (06), 40, 2014 [In Chinese].
26. DONG R.J., DONG Z.B., WU J.F. Evaluation of Desert Ecotourism Suitability. J. Desert. Res. 34(4), 177, 2014 [In Chinese]

27. HE L.X. Evaluation of Ecotourism Suitability of Xiling Snow Mountain. Tourism Overview (the second half of month) 12, 247, 2015 [In Chinese].

28. YE W., XUE X.M. The differences in ecotourism between China and the West. Curr. Issues Tour. 11, 567, 2008.

29. PENG J., YANG Y., LIU Y.X., HU Y.N., DU Y.Y., MEERSMANS J., QIU S.J. Linking ecosystem services and circuit theory to identify ecological security patterns. Sci. Total. Environ. 644, 781, 2018.

30. CHEN Z. A Study on the Problems and Countermeasures of the Development of Rural Ecotourism in China. J. Adv. Econ. Financ. 4, 43, 2019.

31. PENG S.L., LI P., ZHAO Y.J. Analysis of the Ecological Environment Construction Status in Henan Province. Henan Sci 12, 2117, 2015 [In Chinese].

32. EMMANUEL O.O., OLUFEMI A.S., GEORGE O.B. Ecotourism suitability of Okomu and Pendjari National Parks. Anatolia 20, 1, 2018.

33. DHAMI I., DENG J.Y., STRAGER M., CONLEY J. Suitability-sensitivity analysis of nature-based tourism using geographic information systems and analytic hierarchy process. J. Ecotourism. 16 (1), 41, 2016.

34. CHENG Q.P., ZHONG F.L. Evaluation of tourism climate comfort in the Grand Shangri-La region. J. Mt. Sci. 016, 1452, 2019.

35. SHI L.Y., ZHAO H.B., LI Y.L., MA H., YANG S.C., WANG H.W. Evaluation of Shangri-La County's tourism resources and ecotourism carrying capacity. Int. J. Sustain. Dev. World. 22 (2), 103, 2015.

36. TSAUR S.H., LIN Y.C., LIN J.H. Evaluating ecotourism sustainability from the integrated perspective of resource, community and tourism. Tour. Manag. 27, 640, 2006.

37. WU W.J., ZHANG X.L., YANG Z.P., QIN W.M., WANG F., WANG C.R. Ecotourism Suitability and Zoning from the Tourist Perspective: a Nature Reserve Case Study. Pol. J. Environ. Stud. 24, 2683, 2015.

38. MOBARAKI O., ABDOLLAHZADEH M., KAMELIFAR Z. Site suitability evaluation for ecotourism using GIS and AHP: A case study of Isfahan Townships, Iran. Manag. Sci. Lett. 4, 1893, 2014.

39. GAO J., SUN R.H. Ecotourism. Beijing: Higher Education Press. 2010.

40. ÇETINKAYA C., KABAK M., ERBAŞ M., ÖZCEYLAN E. Evaluation of ecotourism sites: a GIS-based multicriteria decision analysis. Kybernetes 47, 1664, 2018.

41. CHEN F.G., LAI M., HUANG H.P. Can marine park become an ecotourism destination? Evidence from stakeholders' perceptions of the suitability. Ocean. Coast. Manage. 196, 105307, 2020.

42. AMBECHA A.B., MELKA G.A., GEMEDA D.O. Ecotourism site suitability evaluation using geospatial technologies: a case of Andiracha district, Ethiopia. Spat. Inf. Res. 2020. 10.1007/s41324-020-00316-y.

43. BUNRUAMKAEW K., MURAYAMA Y.J. Site suitability evaluation for ecotourism using GIS \& AHP: a case study of Surat Thani province, Thailand. Procedia. Soc. Behav. Sci. 21, 269, 2011.

44. CHOW T.E., SADLER R. The consensus of local stakeholders and outside experts in suitability modeling for future camp development. Landscape. Urban. Plan. 94 (1), 9, 2010. 
45. VINCENT V.C., THOMPSON W. Assessing community support and sustainability for ecotouris development. J. Travel. Res. 41 (2), 153, 2002.

46. FORMAN R.T.T. Land mosaics: the ecology of landscapes and regions. Cambridge university press. 1995.

47. THEOBALD D.M. A general model to quantify ecological integrity for landscape assessments and US application. Landscape. Ecol. 28, 1859, 2013.

48. ZELENÝ J., BICKING S., DANG K.B., MÜLLER F. Combining Methods to Estimate Ecosystem Integrity and Ecosystem Service Potentials and Flows for Crop Production in Schleswig-Holstein, Germany. LO 79, 1, 2020.

49. SU S.L., WANG Y.P., LUO F.H., MAI G.C., PU J. Periurban vegetated landscape pattern changes in relation to socioeconomic development. Ecol. Indic. 46, 477, 2014.

50. WALZ U. Landscape Structure, Landscape Metrics and Biodiversity. Living Rev. Landscape Res. 5(5), 1, 2011.

51. LI Y.F., SUN X., ZHU X.D., CAO H.H. An early warning method of landscape ecological security in rapid urbanizing coastal areas and its application in Xiamen, China. Ecol. Model. 221 (19), 2251, 2010.

52. FU W., LIU S.L., DONG S.K. Landscape pattern changes under the disturbance of road networks. Procedia. Environ. Sci. 2, 859, 2010.
53. SUN Q., ZHANG H.W., ZHANG X.H. Resources and environment carrying capacity estimation and the obstacle factors diagnosis for Henan Province. J. Arid. Land. Resour. Environ. 29, 33, 2015.

54. FAN Q.D., DING S.Y. Landscape pattern changes at a county scale: A case study in Fengqiu, Henan Province, China from 1990 to 2013. CATENA 137, 152, 2016.

55. WU Y.Z., ZHANG T.C., ZHANG H., PAN T., NI X.L., GRYDEHØJ A., ZHANG J.M. Factors influencing the ecological security of island cities: A neighborhood-scale study of Zhoushan Island, China. Sustai. Cities and Soc. 55, 102029, 2020.

56. WU J.G. Landscape Ecology: Pattern, Process, Scale and Grade. Beijing: Higher Education Press. 2000.

57. KUMARI S., BEHERA M.D., TEWARI H.R. Identification of potential ecotourism sites in West District, Sikkim using geospatial tools. Tropical. Ecol. 51 (1), 75, 2010.

58. YECHALE M.G., LEUL Y.H. Site Suitability Evaluation of Ecotourism Potentials for Sustainable Natural Resource Management and Community Based Ecotourism Development: The Case of Bench Maji Zone, South Western Part of Ethiopia. Sch. J. Arts Humanit. Soc. Sci. 3 (8B), 1368, 2015. 


\section{Supplementary Material}

Table S1. Selection and calculation of the evaluation index for ecotourism suitability.

\begin{tabular}{|c|c|c|c|}
\hline Index & Code & Description & Calculation formula and classification \\
\hline Naturalness & NL & $\begin{array}{l}\text { It refers to the degree to which the earth's } \\
\text { surface is free from human disturbance. The } \\
\text { higher the degree of naturalness, the higher the } \\
\text { ecotourism suitability. }\end{array}$ & $\begin{array}{l}\text { The NL of different land cover types is classified into } \\
5 \text { levels, with values from } 1 \text { to } 5 \text {. }\end{array}$ \\
\hline $\begin{array}{l}\text { Water } \\
\text { Proximity }\end{array}$ & WP & $\begin{array}{l}\text { It reflects the spatial proximity of a landscape } \\
\text { cell to water bodies (i.e., rivers and lakes). }\end{array}$ & $\begin{array}{l}\text { To calculate the distance between the landscape grid } \\
\text { and the nearest water body and divide it into }<200 \mathrm{~m} \text {, } \\
\begin{aligned} 200 \mathrm{~m}-500 \mathrm{~m}, 500 \mathrm{~m}-1000 \mathrm{~m}, 1000 \mathrm{~m}-3000 \mathrm{~m} \text {, } \\
>3000 \mathrm{~m} \text {; with values from } 5 \text { to } 1 \text {. }\end{aligned}\end{array}$ \\
\hline $\begin{array}{l}\text { Traffic } \\
\text { Proximity }\end{array}$ & ТP & $\begin{array}{l}\text { It reflects the proximity of a landscape cell to } \\
\text { roads. }\end{array}$ & $\begin{array}{l}\text { To calculate the distance between the landscape grid } \\
\text { and the nearest road and divide it into }<500 \mathrm{~m}, 500 \\
\mathrm{~m}-1000 \mathrm{~m}, 1000 \mathrm{~m}-2000 \mathrm{~m}, 2000 \mathrm{~m}-5000 \mathrm{~m},>5000 \\
\mathrm{~m} \text {; with values from } 1 \text { to } 5 \text {. }\end{array}$ \\
\hline $\begin{array}{l}\text { Landscape } \\
\text { Diversity }\end{array}$ & LD & $\begin{array}{l}\text { It refers to the number of landscape types that } \\
\text { exist within a certain spatial range. }\end{array}$ & $\begin{array}{l}\text { To use the landscape types in the unit area to } \\
\text { characterize the landscape diversity index in } \\
\text { the region and use the natural breakpoint method to } \\
\text { divide the LD into } 5 \text { levels, with values from } 1 \text { to } 5 \text {. }\end{array}$ \\
\hline $\begin{array}{l}\text { Vegetation } \\
\text { Coverage }\end{array}$ & $\mathrm{VC}$ & $\begin{array}{l}\text { It is a powerful index for evaluating the } \\
\text { ecological status of a region. The higher the } \\
\text { VC, the higher the ecotourism suitability. }\end{array}$ & $\begin{array}{l}\text { To conduct re-sampling by NDVI data and ArcGIS } \\
\text { software and divide VC into } 5 \text { levels according to the } \\
\text { vegetation status corresponding to the NDVI, with } \\
\text { values from } 1 \text { to } 5 \text {. }\end{array}$ \\
\hline $\begin{array}{c}\text { Relief } \\
\text { Suitability }\end{array}$ & $\mathrm{RS}$ & $\begin{array}{l}\text { It reflects the degree of topographic relief of } \\
\text { landscape patches. The greater the relief, the } \\
\text { higher the natural attributes of the landscape, } \\
\text { and the higher the ecotourism suitability. }\end{array}$ & $\begin{array}{c}\text { To use the Neighborhood Statistics in ArcGIS to } \\
\text { calculate the topographic relief and use the natural } \\
\text { breakpoint method to divide the RS into } 5 \text { levels, } \\
\text { with values from } 1 \text { to } 5 \text {. }\end{array}$ \\
\hline $\begin{array}{l}\text { Climate } \\
\text { Comfort }\end{array}$ & $\mathrm{CC}$ & $\begin{array}{l}\text { Climate comfort is directly proportional to the } \\
\text { ecotourism value, combining the temperature } \\
\text { and humidity index (THI), the cold wind index } \\
\text { (WCI) and the clothing index (ICL). }\end{array}$ & $\begin{array}{l}\text { The CC is divided into } 5 \text { levels, with values from } 1 \\
\text { to } 5 \text {. }\end{array}$ \\
\hline
\end{tabular}

Table S2. Landscape pattern indexes and their ecological significance.

\begin{tabular}{|c|c|c|c|}
\hline Index Type & $\begin{array}{l}\text { Landscape Pattern } \\
\text { Index }\end{array}$ & Code & Ecology Significance \\
\hline \multirow{3}{*}{ Area } & Total Landscape Area & TA & $\begin{array}{l}\text { Refers to the total area of the landscape, determining the scope of the } \\
\text { landscape and the maximum scale of research and analysis. }\end{array}$ \\
\hline & Largest Patch Index & LPI & $\begin{array}{l}\text { The proportion of the largest patch occupied in the landscape area is } \\
\text { used as an indicator to determine the degree of landscape dominance. } \\
\text { The higher the LPI value, the more obvious the advantage is. }\end{array}$ \\
\hline & Mean Patch Area & MPS & $\begin{array}{l}\text { An important indicator representing landscape fragmentation: the total } \\
\text { area of the landscape / the total number of various patches; the larger } \\
\text { the MPS value, the lower the landscape fragmentation. }\end{array}$ \\
\hline \multirow[b]{2}{*}{ Density } & Patch Density & PD & $\begin{array}{l}\text { An important indicator representing landscape fragmentation; the larger } \\
\text { the PD value, the higher the fragmentation. }\end{array}$ \\
\hline & Edge Density & ED & $\begin{array}{l}\text { Reveals the degree to which the landscape is segmented by the } \\
\text { boundary; the larger the ED value, the higher the degree to which the } \\
\text { landscape is segmented by the boundary; on the contrary, the landscape } \\
\text { connectivity is good. }\end{array}$ \\
\hline
\end{tabular}


Table S2. Continued.

\begin{tabular}{|c|c|c|c|}
\hline \multirow[b]{2}{*}{ Shape } & Landscape Shape Index & LSI & $\begin{array}{l}\text { An important indicator representing he complexity of the landscape } \\
\text { shape; the larger the LSI, the more irregular the landscape shape, and } \\
\text { the stronger the interference between the landscapes. }\end{array}$ \\
\hline & $\begin{array}{l}\text { Area-Weighted Mean } \\
\text { Shape Index }\end{array}$ & AWMSI & $\begin{array}{c}\text { An important indicator representing he complexity of the landscape } \\
\text { spatial pattern, and is the sum of the average shape factor of each patch } \\
\text { type multiplied by the weighted value of the type area; the larger the } \\
\text { AWMSI, the more complex and irregular the patch shape, and the more } \\
\text { complicated the spatial pattern. }\end{array}$ \\
\hline \multirow[t]{2}{*}{ Proximity } & Mean Proximity Index & MPI & $\begin{array}{l}\text { MPI can measure the proximity between patches of the same type } \\
\text { and landscape fragmentation; if the MPI value is small, the degree of } \\
\text { dispersion between patches of the same type is high or the degree of } \\
\text { landscape fragmentation is high; if the MPI value is large, the proxim- } \\
\text { ity between patches of the same type is high and the landscape con- } \\
\text { nectivity is good. }\end{array}$ \\
\hline & $\begin{array}{l}\text { Mean Euclidean } \\
\text { Nearest-Neighbor Index }\end{array}$ & MNN & $\begin{array}{l}\text { An important indicator measuring the landscape spatial pattern; } \\
\text { generally speaking, the MNN value is large, the distance between } \\
\text { patches of the same type is relatively long, and the distribution is } \\
\text { relatively discrete; on the contrary, the distance between patches of the } \\
\text { same type is closer and the distribution is agglomerated. }\end{array}$ \\
\hline \multirow{3}{*}{ Vergence } & Contagion Index & CONTAG & $\begin{array}{l}\text { Represents the spread degree of landscape patches; high value indicates } \\
\text { that some patches of the dominance type form good connectivity. }\end{array}$ \\
\hline & Splitting Index & SPLIT & $\begin{array}{l}\text { Represents the fragmentation degree of landscape segmentation, } \\
\text { reflects the complexity of landscape spatial structure, and reflects the } \\
\text { degree of human disturbance to the landscape in some extent; generally } \\
\text { speaking, the larger the SPLIT value, the greater the impact of humans } \\
\text { on the ecosystem. }\end{array}$ \\
\hline & Aggregation Index & AI & $\begin{array}{l}\text { Represents the aggregation degree of landscape; the larger the AI value, } \\
\text { the closer the patches are gathered. }\end{array}$ \\
\hline \multirow[b]{2}{*}{ Diversity } & $\begin{array}{l}\text { Shannon's Diversity } \\
\text { Index }\end{array}$ & SHDI & $\begin{array}{l}\text { Reflects the richness and complexity of the landscape, and describes } \\
\text { the uniformity of the proportion distribution of the area of different } \\
\text { landscape elements; the increase of SHDI value means that patch types } \\
\text { are distributed in an equilibrium trend in the landscape. }\end{array}$ \\
\hline & $\begin{array}{l}\text { Shannon's Evenness } \\
\text { Index }\end{array}$ & SHEI & $\begin{array}{l}\text { SHEI is a powerful tool to compare the diversity changes of different } \\
\text { landscapes or different periods of the same landscape. When the SHEI } \\
\text { value is small, the dominance is generally high, indicating that } \\
\text { the landscape is dominated by one or a few types of dominant patches; } \\
\text { when the SHEI is close to 1, the degree of dominance is low, } \\
\text { indicating that there are no obvious dominance types in the landscape } \\
\text { and all patch types are are evenly distributed in the landscape. }\end{array}$ \\
\hline
\end{tabular}

